\title{
A family study of protracted diarrhoea in infancy
}

\author{
F M HOWARD, C O CARTER, D C A CANDY, AND J T HARRIES \\ From the MRC Clinical Genetics Unit and Department of Child Health, Institute of Child Health, \\ 30 Guilford Street, London WCIN IEH
}

SUMMARY A family study of undiagnosed protracted diarrhoea in infancy was undertaken, based on 67 such patients, seen at The Hospital for Sick Children, London, over a 6-year period. All were fully investigated with the exclusion of those with known cause, such as coeliac disease, cow's milk intolerance, or enteric infections.

The families were traced and visited. The material is certainly heterogeneous. In the case of five patients the condition was associated with a syndrome. The remaining 62 index patients could be divided into a group of 15 with severe illness and 47 with a milder illness. Six had onset before one month of age, four died, and in five the diarrhoea lasted more than 12 months and the children persistently failed to thrive.

These 15 severe cases had six affected sibs out of 22 (Weinberg proband method) and in all but one of these affected sibs the condition was also severe. Two further sibs had had protracted diarrhoea, but this had not been fully investigated. The 47 index patients with milder disease had 68 sibs of whom only one was affected (this boy was one of the severely affected index patients), and one other sib had protracted diarrhoea which was not fully investigated.

It is proposed that the severe group includes one or more autosomal recessive entities, in which the basic defects are not yet known, but are likely to be inborn metabolic errors.

Protracted diarrhoea in infancy is defined as the passage of four or more watery stools per day for more than two weeks, ${ }^{1}$ in association with failure to thrive in a patient under the age of one year. Such children present difficult problems in diagnosis and management. In some patients a diagnosis can be established (for example, coeliac disease, cystic fibrosis, and cow's milk protein intolerance), but in a proportion of cases there is no identifiable cause.

There have been very few reported series of protracted diarrhoea in infancy. Avery et $a l^{2}$ found three undiagnosed cases in a series of 20 , and two of the three died. Lloyd-Still et $a l^{3}$ reported eight undiagnosed cases in a series of 16 and one died. Seven of the ten cases of Hyman et al ${ }^{4}$ also died, and Banister et al $^{5}$ could not make a diagnosis in 13 cases out of their large series of 42 infants. The prevalence in infancy of such undiagnosed cases is unknown.

In a series of 82 cases from The Hospital for Sick Children ${ }^{6}$ a diagnosis could not be established in one quarter of them. In this group without a specific diagnosis, there were a few children who had Received for publication 4 April 1980 cholera-like stools from birth, affected sibs, and a high mortality.

Davidson $e t ~ a l^{7}$ reported five cases of which four had affected sibs and two had first cousin parents. All had crypthypoplastic villous atrophy and four, who had cholera-like stools from birth, died. This series was not an unselected group of patients, but suggests that some cases at least are recessively inherited. Additional evidence for recessive inheritance was provided by the large, but selected, series from three centres of Candy et $a l^{8}$ who studied 26 sibs with protracted diarrhoea from 11 families. We now report a family study of a well investigated, consecutive series of patients, which confirms that these patients include some with one or more autosomal recessive conditions and that these tend to be severe.

\section{Material and methods}

To determine the familial incidence of protracted diarrhoea without known cause, we took a consecutive series of all patients with undiagnosed protracted diarrhoea presenting to one of us $(\mathrm{JH})$ 
over the 6-year period between January 1972 and April 1978. Patients with protracted diarrhoea resulting from coeliac disease, cystic fibrosis, giardiasis, post-gastrointestinal tract surgery, and cow's milk protein intolerance (proved by jejunal biopsy) and a miscellaneous group (for example, defective yeast opsonisation and congenital bile salt deficiency) were excluded. On all patients investigations included: haemoglobin, electrolytes, plasma proteins, immunoglobulins, amino-acids, serum iron, stool and urine microscopy, culture and reducing substances, sweat test, chest $x$-ray, barium meal, and opsonisation index. Jejunal biopsy was performed in two-thirds of the cases. Small intestinal perfusion studies, rectal biopsy, intestinal disaccharides, duodenal flora, and total and individual bile salts were performed where appropriate.

This left 76 cases. We obtained the permission of the family doctors to contact the families of the patients. Family information was obtained by visiting the homes of 65 patients. For two further patients, limited information was obtained by letter. The families of nine patients were not contacted. The reasons for this were: migrated abroad (4), adopted (2), refused permission to visit (2), and not traced (1); this was a boy with itinerant parents, whose affected sister died of protracted diarrhoea.

At the home visit, a pedigree was constructed, and a pregnancy and perinatal history taken for the index patient and sibs. Any report of stillbirth, death, or survival with an abnormality in a sib was verified from medical records. Details of gastrointestinal illness, appetite, allergy, migraine, and other illness were obtained. Height and weight of parents and children were measured.

\section{INITIAL CLASSIFICATION OF PROBANDS}

The numbers in brackets refer to the serial number of the index patient. The 67 index patients satisfied the criteria given above for protracted diarrhoea of infancy. The largest group, 38 cases, had no other abnormalities and only one (No 14, sister of 17) died. These were called group I. The next largest group, 18 cases, comprised similar patients, but who had a history suggestive of cow's milk protein intolerance, although this diagnosis was not confirmed on investigation in hospital. None of these died. These were called group II. A smaller group of six probands, group III, were patients with what would appear to be coincidental associated abnormalities: a retroperitoneal teratoma and pancreatic cyst but with normal pancreatic function (7); sagittal craniostenosis (31); bifid terminal phalanx of the index finger (32); single umbilical artery, spinal haemangioma (45); right dysplastic kidney, intra-abdominal calcification (17); cystic hygroma (L) axilla (36). Four of these died.

A final group of five patients, group IV, had features suggestive of a syndrome. Three of these died. They comprised a possible Russell-Silver dwarf, with triangular face, simple ears, and clinodactyly of the 5th fingers (1); brothers with lissencephaly syndrome and hypogenitalism (patients 2 and 3, both of whom died); a Seckel dwarf (4); ichthyosis and hypo- $\beta$-lipoproteinaemia (No 5 , who died). In this last group it is plausible to suppose that the protracted diarrhoea might be related to the syndrome.

\section{Results}

\section{CLINICAL DATA}

\section{Sex ratio}

The group I patients were equally divided into 19 boys and 19 girls. In the other three groups, there was a male preponderance: 14 males out of 18 , four out of six, and five out of five in groups II, III, and IV, respectively.

\section{Age of onset}

The mean age of onset in the four groups is shown in table 1 . The average (overall) age of onset was 2.7 months, and this did not differ significantly in the different groups or by sex.

\section{Duration of diarrhoea}

The mean duration of the diarrhoea is shown in table 2. There are no significant differences between groups or by sex in the survivors.

\section{Birthweight}

The mean birthweights in the four groups are shown in table 3.

These are unremarkable except in group IV, where all babies were small for dates except No 5 .

TABLE 1 Age of onset (in months)

\begin{tabular}{llllll}
\hline & $M$ & $F$ & Mean & Range & $\begin{array}{c}\text { Onset under } \\
\text { one month }\end{array}$ \\
\hline I & 3.25 & 2.09 & 2.65 & Birth-10 months & $18 / 38$ \\
II & 3.5 & 1.63 & 3.09 & Birth-10 months & $7 / 18$ \\
III & 2.53 & 4.20 & 3.09 & 4 days-8 months & $2 / 6$ \\
IV & 1.19 & - & 1.19 & Birth-4 months & $3 / 5$ \\
\hline
\end{tabular}

TABLE 2 Average duration of diarrhoea (in months), excluding deaths

\begin{tabular}{|c|c|c|c|c|}
\hline & $M$ & $F$ & $\begin{array}{l}\text { Combined } \\
\text { mean } \\
\text { duration }\end{array}$ & Range \\
\hline $\begin{array}{l}\text { I } \\
\text { III } \\
\text { IV }\end{array}$ & $\begin{array}{l}19 \cdot 47 \\
16 \cdot 3 \\
18 \\
17 \cdot 83\end{array}$ & $\begin{array}{l}12 \cdot 44 \\
18 \cdot 5 \\
12 \\
-\end{array}$ & $\begin{array}{l}13 \cdot 35 \\
17 \cdot 92 \\
16 \cdot 00 \\
17 \cdot 83\end{array}$ & $\begin{array}{l}\text { 5-52 (excluding } 1 \text { dying) } \\
2-44 \text { (no deaths) } \\
12-18 \text { (excluding } 3 \text { dying) } \\
20-30 \text { (excluding } 3 \text { dying) }\end{array}$ \\
\hline
\end{tabular}


TABLE 3 Birthweight in $k g$

\begin{tabular}{lllll}
\hline & $M$ & $F$ & Mean & Range \\
\hline I & $3 \cdot 35$ & $2 \cdot 89$ & $3 \cdot 12 \mathrm{~kg}$ & $1 \cdot 7-4$ \\
II & $3 \cdot 386$ & $3 \cdot 00$ & $3 \cdot 3$ & $2 \cdot 2-4 \cdot 6$ \\
III & $3 \cdot 24$ & $2 \cdot 60$ & $3 \cdot 13$ & $2 \cdot 2-4 \cdot 5$ \\
IV & $2 \cdot 66$ & - & $2 \cdot 66$ & $2 \cdot 3-3 \cdot 5$ \\
\hline
\end{tabular}

SEARCH FOR ENVIRONMENTAL FACTORS

No significant trends were observed after analysis for birth order, maternal age, season of birth, conception, or socioeconomic class.

\section{Events in pregnancy}

No consistent history of drugs or infections in pregnancy was obtained.

\section{Initial feeding}

The majority of babies received artificial feeds from birth. Only one quarter were breast fed for more than one week (group I and III 10/44; group II $6 / 18$ ), as compared with $42 \%$ overall in England and Wales in $1975 .^{9}$

\section{FAMILY DATA}

The family data collected at interview are summarised in the appendix.

\section{Parental consanguinity}

In group I, two patients (8) and (32) had parents who were first cousins. These parents came from Bangladesh and Egypt, respectively. Another patient's (37) parents were second cousins from Pakistan. In group II there were two marriages (64) (65) between first cousins once removed (these parents came from England and Scotland) and one (59) between Maltese third cousins.

\section{Twins}

Only one pair of twins was recorded among the index patients. These were No 55 and 56 male
TABLE 5 Proportion of affected sibs (excluding twins) of probands (Weinberg proband method)

\begin{tabular}{|c|c|c|c|c|c|}
\hline & \multirow{2}{*}{$\begin{array}{l}\text { Brothers } \\
\text { Before }\end{array}$} & \multirow[b]{2}{*}{ After } & \multirow{2}{*}{ Sisters } & \multirow[b]{2}{*}{ After } & \multirow{2}{*}{$\begin{array}{l}\text { Total } \\
\text { affected }\end{array}$} \\
\hline & & & & & \\
\hline $\begin{array}{c}\text { Group I } \\
\text { II } \\
\text { III } \\
\text { IV }\end{array}$ & $\begin{array}{l}1 / 16 \\
0 / 7 \\
1 / 2 \\
1 / 2\end{array}$ & $\begin{array}{l}1 / 11 \\
0 / 1 \\
0 / 3 \\
1 / 3\end{array}$ & $\begin{array}{l}2 / 27 \\
0 / 10 \\
1 / 5 \\
0 / 1\end{array}$ & $\begin{array}{l}1 / 3 \\
0 / 5 \\
0 / 0 \\
0 / 1\end{array}$ & $\left.\begin{array}{l}5 / 57 \\
0 / 23 \\
2 / 10 \\
2 / 7\end{array}\right\} 9 / 97$ \\
\hline
\end{tabular}

monozygotic twins both with onset of diarrhoea at 5/52 when breast feeding was stopped. Thus these were placed in group II, although both have vesicoureteric reflux.

\section{Sibs (excluding twins)}

The findings in sibs are summarised in tables 4 and 5. Altogether there were seven families with two affected children. In three of the families $(23,31,46)$ there was clearly only one proband; the other sib was treated elsewhere. In the other four families $(2 / 3,14 / 17,33 / 42,55 / 56)$ both sibs were index patients in the series. Each sib was probably (but not necessarily) independently ascertained and so both are taken as a proband in table 5 , though it is difficult to know when two sibs are referred to a hospital whether they are independent referrals.

A further four sibs may have been affected. These were investigated elsewhere and full details are not available so they were not classed as affected.

Group I. (1) Male sib of 9: diarrhoea from first month; still failing to thrive at one year on glutenfree, lactose-free diet.

(2) Female sib of 19: diarrhoea from 5 months; pathogenic $E$ coli originally found in stools; persistent diarrhoea until 26 months with height and weight on 10th centile; labelled 'milk sensitivity'.

(3) Male sib of 29: diarrhoea from 3 months; failure to thrive at 15 months and treated with gluten-free diet up to the age of 4 years; no jejunal biopsy performed.

TABLE 4 Probands with affected sibs

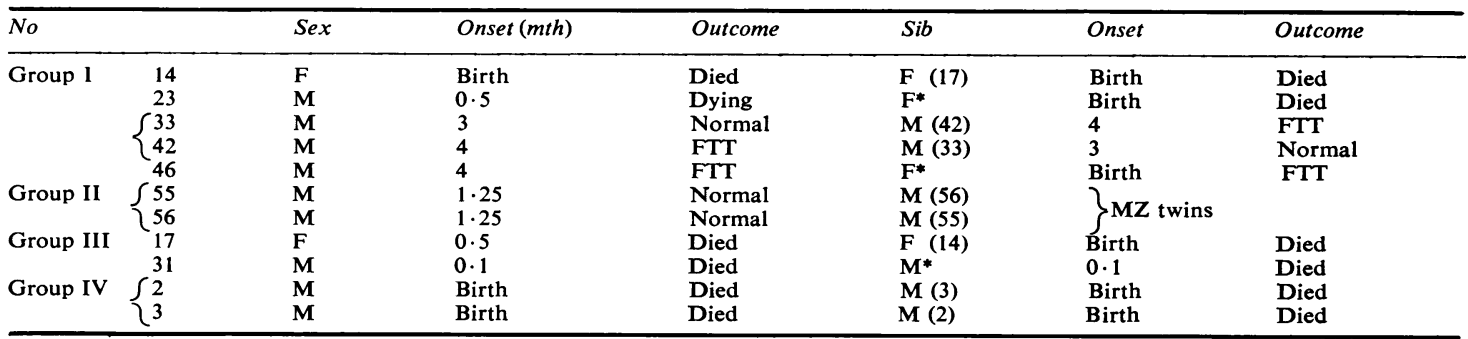

FTT $=$ persistent failure to thrive. Weight and height less than 3 rd centile at home visit.

*Not treated at The Hospital for Sick Children. 
Group II. (4) Female sib of 51: diarrhoea 5 months to 2 years; possible intolerance to cow's milk protein.

\section{CLASSIFICATION BY OVERALL SEVERITY}

Taking a fatal outcome, or duration of diarrhoea for more than one year and subsequent persistent failure to thrive (that is, remaining below the 3rd centile for height and weight, measured between one and 11 years after the diarrhoea had ceased), it is possible to divide group I and III into a severely affected group of 15 index patients, eight male and seven female (No 9, 10,11, 14, 17, 18, 23, 29, 31, $35,40,42,44,46,47)$ and a milder group of 47 cases. Eleven cases in group I, none in group II, and four in group III were severe (see appendix). Six of these cases had an early onset (less than one month of age).

None of the probands in group II later failed to thrive, although seven had an early onset and eight had a late onset and prolonged diarrhoea. In group IV, four developed diarrhoea at birth. Three of these died and the two survivors had a prolonged course and both are dwarfed.

It is noteworthy that in three instances in groups I to III where the patient died (see table 4), the affected sib also died. There may well be a fourth concordant pair, as case 23, after 2 years of almost continuous parental alimentation, and severe failure to thrive, is now dying. Index patient 46 and his sib (fully investigated elsewhere) were both severely affected but are surviving, although failing to thrive. Two other index cases $(10,29)$ also possibly have affected sibs who are still failing to thrive, but as these sibs have not been investigated as fully as our cases we have not included them in our calculations. The sib pair 33 and 42 are interesting, as both had a later onset of diarrhoea ( 3 and 4 months), but prolonged duration (52 and 29 months, respectively). One (33) has recovered fully when measured 56 months after diarrhoea had ceased but the other (42) is still well below the 3rd centile for height and weight 20 months after cessation of symptoms.

We separated off this severe group from groups I to III after visiting the families and reviewing the notes, as we feel this is a special group meriting further study of their underlying defect. This group was still failing to thrive months or years after clinically similar cases had fully recovered. Intelligence in all cases was normal, and the failure to thrive could not be attributed to the family pattern of height and weight, as their parents and sibs all fell within the normal range.

\section{Discussion of genetic mechanisms}

Overall, nine of 97 sibs of index patients with protracted diarrhoea were also affected. This is too low a proportion to be compatible with simple autosomal recessive inheritance. However, the patients are almost certainly heterogeneous. The group IV patients with syndromes, or presumed syndromes, may be considered separately. In this group, two of seven sibs were affected. Seckel syndrome (No 4) is a known recessive condition and the two brothers (2 and 3) with lissencephaly also probably have an unrecognised recessive syndrome.

For the remaining 62 index patients without other abnormalities, or whose abnormalities would appear coincidental, seven of 90 sibs were affected. However, further heterogeneity is probably present. Considering the 15 seriously affected index patients (see above), the proportion of sibs affected is six in 22 .

Further, the severity of the condition in the index patient and affected sib is similar (see table 4), except for the pair 33 and 42 , where 42 persistently failed to thrive, but 33 , in spite of a long duration of diarrhoea, recovered fully. The proportion of sibs affected in this severe group is entirely compatible with autosomal recessive inheritance. The condition is similar clinically to the four sib pairs with lethal protracted diarrhoea reported by Davidson et al except that their patients had crypthypoplastic villous atrophy and none of our cases had this finding on jejunal biopsy.

In the other group of 47 less severely affected index patients (which includes all of the patients in group II), the proportion of sibs affected is one in 68. The affected sib was No 33, whose brother, No 42, was severely affected (suggesting that 33 might essentially belong to the severe group). In the remainder of the milder cases there is little evidence of genetic determination.

\section{Conclusions}

While cases of protracted diarrhoea in infancy of unknown cause are clearly heterogeneous, there are some that probably constitute an autosomal recessive entity or entities. These patients are characterised often, but not always, by an early onset and by the severity and duration of the diarrhoea, ending in death or in persistent severe growth retardation. The primary defect is not known and there are no characteristic histological appearances of the intestinal mucosa.

The birth frequency of the condition is not known, but the 16 patients with the severe form were seen at The Hospital for Sick Children over 6 years, that is about three cases a year. This may be compared with some six new cases a year of phenylketonuria, which in south-east England has a birth frequency of a little under $1 \times 10^{-5}$, as the pattern of referral is not dissimilar. 
The milder cases of shorter duration and with recovery show a much smaller degree of familial concentration and there is no strong indication that these cases are genetically determined.

D C A Candy gratefully acknowledges the financial support of the Rayne Foundation.

\section{References}

1 Challacombe DN, Richardson JM, Rowe B, Anderson CM. Bacterial microflora of the upper gastrointestinal tract in infants with protracted diarrhoea. Arch Dis Child 1974;49:270-7.

2 Avery SB, Villavicencio O, Lilly JR, Randolph JG. Intractable diarrhoea in early infancy. Pediatrics $1968 ; 41$ : 712-22.

s Lloyd-Still JD, Shwachmann H, Filler RM. Protracted diarrhea of infancy treated by intravenous alimentation. Am J Dis Child 1973;125:358-64.
4 Hyman CJ, Reiter J, Rodnan J, Drash AL. Parental and oral alimentation in the treatment of the non specific protracted diarrhoea syndrome of infancy. $J$ Pediatr 1971; 78:17-29.

5 Banister A, Matin-Siddiqi SA, Hatcher CW, Henderickse RG. Intravenous feeding of young infants with persistent diarrhoea. Acta Paediatr Scand 1975;64: 732-40.

6 Larcher VF, Shepherd R, Francis DEM, Harries JT. Protracted diarrhoea in infancy. Arch Dis Child 1977;52: 597-605.

7 Davidson GP, Cutz E, Hamilton JR, Gall DG. Familial enteropathy: a syndrome of protracted diarrhoea from birth, failure to thrive and hypoplastic villous atrophy. Gastroenterology 1978;75:783-90.

8 Candy DCA, Larcher VF, Tripp JH, et al. Lethal familial protracted diarrhoea of infancy. Arch Dis Child (in press).

9 Martin J. Infant feeding 1975. Attitudes and practice in England and Wales. London: HMSO, 1975: 15.

Requests for reprints to Professor C O Carter, MRC Clinical Genetics Unit, Institute of Child Health, 30 Guilford Street, London WC1N 1EH.

APPENDIX Groups, index patients, and sibs

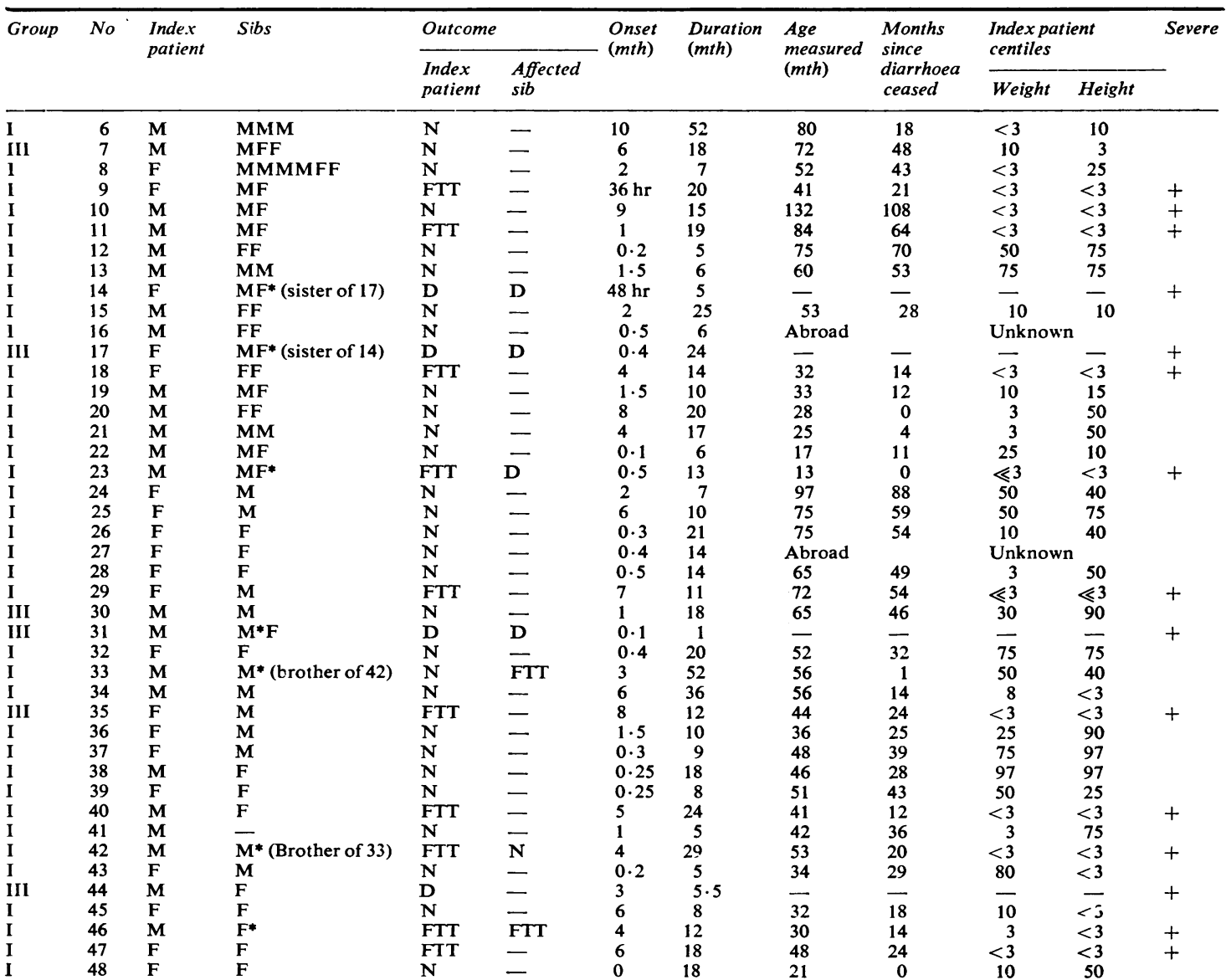


APPENDIX-continued

\begin{tabular}{|c|c|c|c|c|c|c|c|c|c|c|c|c|}
\hline \multirow[t]{2}{*}{ Group } & \multirow[t]{2}{*}{ No } & \multirow[t]{2}{*}{$\begin{array}{l}\text { Index } \\
\text { patient }\end{array}$} & \multirow[t]{2}{*}{ Sibs } & \multicolumn{2}{|c|}{ Outcome } & \multirow[t]{2}{*}{$\begin{array}{l}\text { Onset } \\
(m t h)\end{array}$} & \multirow[t]{2}{*}{$\begin{array}{l}\text { Duration } \\
\text { (mth) }\end{array}$} & \multirow{2}{*}{$\begin{array}{l}\text { Age } \\
\text { measured } \\
(\text { mth })\end{array}$} & \multirow{2}{*}{$\begin{array}{l}\text { Months } \\
\text { since } \\
\text { diarrhoea } \\
\text { ceased }\end{array}$} & \multicolumn{2}{|c|}{$\begin{array}{l}\text { Index patient } \\
\text { centiles }\end{array}$} & \multirow[t]{2}{*}{ Severe } \\
\hline & & & & $\begin{array}{l}\text { Index } \\
\text { patient }\end{array}$ & $\begin{array}{l}\text { Affected } \\
\text { sib }\end{array}$ & & & & & Weight & Height & \\
\hline $\mathbf{I}$ & 49 & $\mathbf{F}$ & - & $\mathbf{N}$ & - & 3 & 10 & 34 & 21 & 50 & 75 & \\
\hline II & 50 & $\mathbf{M}$ & MFF & $\mathbf{N}$ & - & 3 & $2 \cdot 2$ & 74 & 69 & 50 & $<3$ & \\
\hline II & 51 & $\mathbf{M}$ & $\mathbf{F}$ & $\mathbf{N}$ & 一 & 7 & 13 & 60 & 40 & 50 & 50 & \\
\hline II & 52 & $\mathbf{M}$ & FF & $\mathbf{N}$ & - & 0.25 & 15 & 54 & 51 & 10 & 10 & \\
\hline II & 53 & $\mathbf{M}$ & MM & $\mathbf{N}$ & - & 5 & 20 & 45 & 20 & 3 & 10 & \\
\hline II & 54 & $\mathbf{M}$ & FF & $\mathbf{N}$ & - & 0 & 11 & 26 & 15 & 50 & 75 & \\
\hline II & 55 & $\mathbf{M}$ & $\mathcal{Z}^{*} \mathbf{M Z} \mathrm{M}$ & $\mathbf{N}$ & $\mathbf{N}$ & $1 \cdot 25$ & 14 & 14 & 0 & 50 & 25 & \\
\hline II & 56 & $\mathbf{M}$ & \}$*$ Twins & $\mathbf{N}$ & $\mathbf{N}$ & $1 \cdot 25$ & 14 & 14 & 0 & 75 & 50 & \\
\hline II & 57 & $\mathbf{M}$ & $\mathbf{F}$ & $\mathbf{N}$ & - & 10 & 26 & 93 & 57 & 50 & 60 & \\
\hline II & 58 & $\mathbf{M}$ & $\mathbf{F}$ & $\mathbf{N}$ & - & 0.25 & 5 & 90 & 85 & 30 & 30 & \\
\hline II & 59 & $\mathbf{F}$ & $\mathbf{M}$ & $\mathbf{N}$ & - & 5 & 42 & 94 & 47 & 50 & 40 & \\
\hline II & 60 & M & $\mathbf{F}$ & $\mathbf{N}$ & - & 3 & 24 & 84 & 57 & 25 & 25 & \\
\hline II & 61 & $\mathbf{M}$ & $\mathbf{F}$ & $\mathbf{N}$ & - & 8 & 44 & 81 & 29 & 50 & 20 & \\
\hline II & 62 & $\mathbf{M}$ & $\mathbf{M}$ & $\mathbf{N}$ & - & 5 & 30 & 54 & 19 & 20 & 75 & \\
\hline $\mathbf{I I}$ & 65 & $\mathbf{F}$ & $\mathbf{F}$ & $\mathbf{N}$ & 一 & 1 & 10 & 16 & 5 & 10 & 10 & \\
\hline II & 66 & $\mathbf{F}$ & - & $\mathbf{N}$ & - & 0 & 10 & 25 & 15 & 3 & 3 & \\
\hline II & 67 & $\mathbf{F}$ & MMF & $\mathbf{N}$ & - & 0.5 & 12 & 72 & 60 & 3 & 3 & \\
\hline IV & 1 & $\mathbf{M}$ & MFF & FTT & - & 4 & 20 & 35 & 11 & $<3$ & $<3$ & \\
\hline IV & 2 & $\mathbf{M}$ & $\left.\mathbf{M}^{*}\right\}_{\text {Brothers }}$ & D & $\mathbf{D}$ & 0 & $3 \cdot 5$ & - & - & - & - & \\
\hline IV & 3 & $\mathbf{M}$ & $\left.\mathbf{M}^{*}\right\}$ Brothers & $\overline{\mathbf{D}}$ & $\bar{D}$ & 0 & $2 \cdot 5$ & - & - & - & - & \\
\hline IV & 4 & $\mathbf{M}$ & $\mathbf{M}$ & FTT & - & $1 \cdot 75$ & 30 & 53 & 23 & $<3$ & $<3$ & \\
\hline IV & 5 & $\mathbf{M}$ & $\mathbf{M}$ & D & 一 & 0.2 & $3 \cdot 5$ & - & 一 & - & - & \\
\hline
\end{tabular}

Numbered according to initial grouping, then number in sibship, then chronologically. D, died; FTT, failure to thrive; * affected. 